\title{
PHENOTYPIC AND GENOTYPIC CHARACTERIZATION OF PSEUDOMONAS SAVASTANOI PV. SAVASTANOI CAUSING OLIVE KNOT DISEASE IN TURKEY
}

\author{
BASIM, H. ${ }^{*}-$ BASIM, $^{2}{ }^{2}-$ ERSOY, A. $^{3}$ \\ ${ }^{I}$ Department of Plant Protection, Akdeniz University, Antalya, Turkey \\ ${ }^{2}$ Department of Organic Agriculture, Akdeniz University, Antalya, Turkey \\ ${ }^{3}$ Antalya Directorate of Agricultural Quarantine, Antalya, Turkey \\ *Corresponding author \\ e-mail: hbasim@akdeniz.edu.tr; phone: +90-242-310-2432; fax: +90-242-227-4564
}

(Received 20 $0^{\text {th }}$ Jun 2019; accepted $16^{\text {th }}$ Oct 2019)

\begin{abstract}
Olive knot disease caused by Pseudomonas savastanoi pv. savastanoi (Psv) is one of the major diseases influencing olive (Oleae europaea L.) production in Turkey. The disease incidence rate was found to range between 4 and $80 \%$ according to the 2015 and 2018 surveys. A total of 67 isolates were recovered from 7 symptomatic Turkish olive cultivars on a semi-selective medium, PVF-1, and then identified as Psv by biochemical and molecular tests. The isolates produced characteristic gall symptoms on olive plants and were consistently re-isolated. Fatty acid methyl ester (FAME) analysis indicated that the major fatty acid components were oleic acid (18:1), palmitoleic acid (16:1), and palmitic acid (16:0), and also clustered the olive strains into 2 groups. The repetitive element palindromic PCR (rep-PCR) primer, the BOXA1R primer, produced the discriminatory profile, with amplicon sizes ranging from $200 \mathrm{bp}$ to $2 \mathrm{~kb}$, and categorized the olive strains into 2 separate groups. Pulsed-Field Gel Electrophoresis (PFGE) differentiated the olive Psv isolates into 3 discrete haplotype groups after the genomic DNA was digested with SpeI. This is the first study using PFGE to determine the genetic diversity of the Psv olive population.
\end{abstract}

Keywords: FAME, Rep-PCR, olive knot, PFGE, Psv

\section{Introduction}

The olive tree (Olea europaea L.) is a standout amongst the most significant and transcendent organic product trees found in western and focal Italy and Spain, southern Morocco and Tunisia, and western Turkey, and Greece (Loumou and Giourga, 2003). It serves as a source of edible fruit and oil for millions of people in various parts of Turkey. At present, global olive oil production exceeds 2,500,000 tons. In 2015, the aggregate production by the member states of the International Olive Oil Council (IOC) was 2,964,500 tons, $94 \%$ of the global production. EU production was 2,322,000 tons, whereas the individual IOC member state production showed Spain to be leading with 1,401,600 tons, followed by Italy with 474,600 tons, and then by Greece with 320,000 tons. Turkey produced 143,000 tons, Tunisia 140,000 tons, Morocco 130,000 tons, Algeria 83,500 tons, and Iran 5,000 tons (International Olive Oil Council, 2015). Olive knot disease is perhaps the earliest plant disorder to be specifically reported in ancient times, and is regarded as one of the most critical diseases that affects olive trees.

Olive knot disease is characterised by the production of hyperplastic galls on several plant parts (Nester and Kosuge, 1981). The disease is a serious threat to olive production in the Mediterranean basin, including Turkey, where several climatic conditions including rain, wind, humidity, and temperature favour pathogen 
dissemination, growth, development, and infection processes. In Turkey, the disease is known to be infect olive (Olea sp.), oleander (Nerium oleander), fontanesia (Fontanesia phillyreoides), myrtle (Myrtus communis), and jasmine (Jasminium officinale) in Çanakkale, Muğla, Antalya, Samsun, Şanlıurfa, Bursa, Izmir, Tekirdağ, Adana, Mersin, and Hatay provinces (Basım and Ersoy, 2000; Tatlı and Benlioğlu 2004; Kavak and Üstün 2009; Mirik et al., 2011).

The development of olive knots relies on the ability of $P s v$ to synthesise and secrete cytokinins and indolacetic acid (IAA) (Surico et al., 1985; Perez-Martínez et al., 2007; Quesada et al., 2010) as well as the functionality of its Type Three Secretion System (Sisto et al., 2004; Perez-Martinez et al., 2010; Tegli et al., 2011). Moreover, the capacity of $P s v$ to actuate olive knot arrangement depends on the quorum sensing intercellular communication system moderated by $\mathrm{N}$-acyl homoserine lactone (Hosni et al., 2011). The disease affects the yield and vegetative parts of the olive plants, and quality of olive oil (Schroth et al., 1973).

Members of $P$. syringae, including $P s v$, have been previously identified based on plasmid fingerprints (King, 1989), fatty acid fingerprinting (Stead, 1992), and analysis of protein (Van Zyl and Steyn, 1990). Recently, DNA profiling techniques such as Restriction Fragment Length Polymorphism (RFLP) (Manceau and Horvais, 1997), Amplified Fragment Length Polymorphism (AFLP), (REP)-REP1-1/REP2-1 (Sharples and Lioyd, 1990), Enterobacterial Repetitive Intergenic Consensus (ERIC)ERIC1R/ERIC2 (Hulton et al., 1991), and BOXA1R (Louws et al., 1994), Randomly Amplified Polymorphic DNA (Krid et al., 2009), Pulsed-field gel electrophoresis (PFGE) (Chu et al., 1986), Multi Locus Sequence Typing (MLST) analysis of housekeeping genes (Berge et al., 2014), and a set of primers (Guilbaud et al., 2016) have been applied in genotyping and investigating strains and pathovars of $P$. syringae. The whole genome of PSv has also been sequenced and annotated (RodriguezPalenzuela et al., 2010). Although there are reports of the presence and identification of $P s v$ in west Mediterranean region of Turkey (Basim and Ersoy 2000, 2001), few studies have been conducted to characterize this pathogen in detail.

The objective of this study was to evaluate the phenotypic and genotypic features of the Psv olive population in west Mediterranean region of Turkey by gas chromatographic analysis of fatty acid methyl esters (GC-FAME), repetitive element palindromic PCR (rep-PCR), and PFGE. To our knowledge, this is the first study of using PFGE to determine the genetic diversity of the $P s v$ olive population.

\section{Materials and methods}

\section{Sample collection}

Samples were collected from olive trees showing symptoms of suspected knot disease by random sampling of different olive orchards in the districts of Antalya Center ( 7 orchards; 82 olive trees), Serik ( 3 orchards; 49 olive trees), Aksu (4 orchards; 35 olive trees), Kaş ( 6 orchards; 96 olive trees) and Döşemealtı ( 3 orchards; 58 olive trees) in the Western Mediterranean district of Turkey during May-August of 2015 and MayAugust of 2018. Samples from different local cultivars of olive trees such as Gemlik, Memeli, Ayvalık, Edinciksu, Edremit, Kan, and Memecik were collected for bacterial isolation. Approximately 320 olive trees in 23 orchards in total were surveyed. The samples were packaged and transported to the Department of Plant Protection of Akdeniz University, where the putative pathogen was isolated. Psv isolates (PssI2, 
PssI7, PssI21, PssI24, Psn9) obtained from surveys in Antalya province of Turkey in 2000 (Basim and Ersoy, 2000) were also included in this study (Table 2). The Myrtus strain, PssI24, and Nerium strain, Psn9, were used for clustering. The disease rates within the olive plantations from which the contaminated samples were collected were assessed utilizing the equation as defined by Bansal et al. (1994):

Disease incidence $(D I)(\%)=($ Number of diseased plants $/$ Total number of plants $) \times 100$

\section{Isolation and identification of bacteria}

Bacterial isolation was carried out on olive knots present on two-year-old twigs. Plant surfaces were disinfected using paper towel saturated with $96 \%$ ethanol; the decayed sections within the hyperplastic knot tissues were then cut off and grounded in sterile phosphate buffer $\left(0.05 \mathrm{M} \mathrm{Na}_{2} \mathrm{HPO}_{4}, 4.26 \mathrm{~g} ; \mathrm{K}_{2} \mathrm{HPO}_{4}, 2.72 \mathrm{~g} ; 1000 \mathrm{ml}\right.$ sterile $\mathrm{dH}_{2} \mathrm{O}$ ). A loop of bacterial suspension was streaked onto semi-selective PVF-1 medium (glycerol, $10 \mathrm{ml}$; sucrose, $30 \mathrm{~g}$; casamino acid, $2.5 \mathrm{~g}$; $\mathrm{K}_{2} \mathrm{HPO}_{4} 3 \mathrm{H}_{2} \mathrm{O}, 1.96 \mathrm{~g}$;

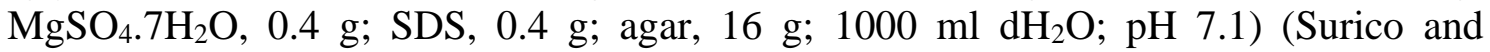
Lavermicocca, 1989), King's B medium (KB; protease peptone, $20 \mathrm{~g}$; Bacto agar, $20 \mathrm{~g}$; glycerol, $10 \mathrm{ml} ; \mathrm{K}_{2} \mathrm{HPO}_{4}, 1.5 \mathrm{~g} ; \mathrm{MgSO}_{4}, 1.5 \mathrm{~g} ; 1000 \mathrm{ml} \mathrm{dH} 2 \mathrm{O}, \mathrm{pH}$ 7.2) (King et al., 1954) and Nutrient Sucrose Agar (NSA) (Nutrient Broth, 4.8 g; Bacto agar, 9 g;

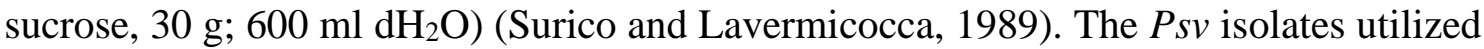
in this study are listed in Table 2. The bacteria were incubated at $28{ }^{\circ} \mathrm{C}$ on PVF-1, KB, and NSA media. Bacterial fluorescent pigment production was examined under UV light at $364 \mathrm{~nm}$. In all, 67 isolates identified as $P s v$ were recovered, then freezed in glycerol $(30 \%)$ at $-86{ }^{\circ} \mathrm{C}$ for long term storage and further analysis.

Putative Psv isolates were identified by several biochemical tests, including LOPAT, according to Schaad et al. (2001). The tests were carried out using flat, greyish-white, irregular margins or semi-translucent colonies grown on PVF-1 medium. The identity of the Psv isolates was confirmed by GC-FAME analysis (Stead, 1992) and PCR. The Psv isolates were identified directly from bacterial suspension as well as from purified genomic DNA by PCR utilizing primers, IAALN1/IAALN2 (Pelyaver et al., 2000) and PSS1/PSS2; PSS3/PSS4 (Basim and Ersoy, 2001). The polymerase chain reaction (PCR) conditions are given in Table 1.

\section{Pathogenicity test}

For putative Psv isolates, pathogenicity tests were carried out by inoculating the stems of a one-year-old Gemlik olive cultivar. The bark of the stem was wounded with a sterilized needle dipped in bacterial suspension, which contained $\sim 10^{8} \mathrm{CFU} / \mathrm{ml}$, and the wounds were then covered with Parafilm for 3 days. The inoculated olive plants were kept in a controlled-room at $25 \pm 2{ }^{\circ} \mathrm{C}$ and $80-85 \% \mathrm{RH}$ and monitored for symptom development according to Surico and Lavermicocca (1989). Olive plants similarly treated with reference strains or sterile $\mathrm{dH}_{2} \mathrm{O}$ were utilized as positive and negative controls, respectively.

\section{GC-FAME analysis}

GC-FAME analyses were performed on each $P s v$ isolate as stated in the manufacturer's specifications to determine the phenotypic characteristic of the isolates. The Psv isolates were growth on tryptic soy broth agar at $27^{\circ} \mathrm{C}$ for $24 \mathrm{~h}$. The each Psv 
isolate (a loopful) was blended within a glass tube containing $1.2 \mathrm{~N} \mathrm{NaOH}$ in methanol: $\mathrm{H}_{2} \mathrm{O}$. The tubes were shortly vortexed, kept in a bubbling water bath for $5 \mathrm{~min}$. The tubes firmly vortexed once more for $10 \mathrm{~s}$ and were exchanged to the bubbling water bath for 30-min warming to finish reaction. Two ml methylation arrangement $(325 \mathrm{ml}$ $6.0 \mathrm{~N}$ hydrochloric acid, $275 \mathrm{ml}$ methyl solution) was included to the tubes after the tubes were cooled to room temperature. The samples were without further ado vortexed, warmed at $80{ }^{\circ} \mathrm{C}$ for $10 \mathrm{~min}$. The samples were cooled quickly on ice, and afterward $1.25 \mathrm{ml}$ the extraction arrangement (N-hexane/methyl tert-butyl ether $(1: 1 ; \mathrm{v} / \mathrm{v})$ was included. The samples were tenderly blended utilizing a tube revolver for $10 \mathrm{~min}$. The under aqueous phases of the samples were discarded by a micropipette. Three milliliters of the sample clean up solution $\left(10.8 \mathrm{~g} \mathrm{NaOH}\right.$ dissolved in $\left.900 \mathrm{ml} \mathrm{H}_{2} \mathrm{O}\right)$ was included into the sample, and tenderly blended for $5 \mathrm{~min}$. And after that $\sim 2 / 3$ of natural period of the examples was moved into a dull GC vial. These final extracts were analysed with the HP 6980 GC System (Agilent Technologies, CA, USA), and the MIDI system (Microbial ID Inc., USA) with a $25 \mathrm{~m} \times 0.2 \mathrm{~mm}$ silica capillary column was performed. The 67 isolates of $P s v$ were identified, and phenotypically characterized based on FAME composition by dendrogram analysis using the MIDI software version 6.0.

Table 1. PCR primers used in this study

\begin{tabular}{|c|c|c|c|c|c|}
\hline Locus & Primers & Sequence $\left(5^{\prime} \rightarrow 3^{\prime}\right)$ & Size (bp) & References & Conventional PCR conditions \\
\hline \multirow{2}{*}{$P t z$} & PSS1 & TGGGGTGCTACTTGTACCGGA & \multirow{2}{*}{684} & \multirow{2}{*}{$\begin{array}{l}\text { Basım and Ersoy } \\
\text { (2001) }\end{array}$} & \multirow{2}{*}{$\begin{array}{c}5 \text { min at } 95^{\circ} \mathrm{C} \text {, followed by } 35 \\
\text { cycles, } 30 \text { s at } 95^{\circ} \mathrm{C}, 30 \text { s at } 62^{\circ} \mathrm{C} \\
45 \text { s at } 72{ }^{\circ} \mathrm{C}, 5 \text { min at } 72{ }^{\circ} \mathrm{C}\end{array}$} \\
\hline & PSS2 & CCGTGTACTACGTTCAGCGAG & & & \\
\hline \multirow{2}{*}{$i a a \mathrm{~L}$} & PSS3 & CAGGACTTCAGAACCCACGT & \multirow{2}{*}{1064} & \multirow{2}{*}{$\begin{array}{l}\text { Basım and Ersoy } \\
\text { (2001) }\end{array}$} & \multirow{2}{*}{$\begin{array}{l}5 \text { min at } 95^{\circ} \mathrm{C} \text {, followed by } 35 \\
\text { cycles, } 30 \text { s at } 95^{\circ} \mathrm{C}, 30 \text { s at } 62^{\circ} \mathrm{C} \text {, } \\
45 \text { s at } 72{ }^{\circ} \mathrm{C}, 5 \text { min at } 72{ }^{\circ} \mathrm{C}\end{array}$} \\
\hline & PSS4 & CGGTCGATGATGTAGAGCAT & & & \\
\hline \multirow{2}{*}{$i a a \mathrm{~L}$} & IAALF & GGCACCAGCGGCAACATCAA & \multirow{2}{*}{454} & \multirow{2}{*}{$\begin{array}{c}\text { Pelyalver et al. } \\
\text { (2000) }\end{array}$} & \multirow{2}{*}{$\begin{array}{c}5 \text { min at } 94{ }^{\circ} \mathrm{C} \text {, followed by } 35 \\
\text { cycles, } 30 \text { s at } 94{ }^{\circ} \mathrm{C}, 30 \text { s at } 62{ }^{\circ} \mathrm{C} \text {, } \\
30 \text { s at } 72{ }^{\circ} \mathrm{C}, 5 \text { min at } 72{ }^{\circ} \mathrm{C} \mathrm{m}\end{array}$} \\
\hline & IAALR & CGCCCTCGGAACTGCCATAC & & & \\
\hline BOX-PCR & BOXA1R & CTACGGCAAGGCGACGCTGACG & & $\begin{array}{l}\text { Louws et al. } \\
\text { (1994) }\end{array}$ & $\begin{array}{c}7 \text { min at } 95^{\circ} \mathrm{C} \text {, followed by } \\
30 \text { cycles, } 1 \text { min at } 94{ }^{\circ} \mathrm{C}, 1 \mathrm{~min} \text { at } \\
53{ }^{\circ} \mathrm{C}, 8 \mathrm{~min} \text { at } 65^{\circ} \mathrm{C}, 15 \mathrm{~min} \text { at } \\
65^{\circ} \mathrm{C}\end{array}$ \\
\hline
\end{tabular}

\section{DNA extraction}

Genomic DNA from Psv isolates was extracted based on a modified CTAB method (Doyle and Doyle, 1990), and was dissolved in $50 \mu \mathrm{TE}$ buffer. The concentration of DNA was adjusted to $100 \mathrm{ng} / \mu 1$ with TE, using a Nanodrop (Thermo Fisher Scientific, Waltham, MA, USA) and after which the DNA solution was stored at $4{ }^{\circ} \mathrm{C}$.

\section{Rep-PCR}

Evaluation of genetic differences among Psv was performed by Rep-PCR using primer based on repetitive extragenic palindromic (REP) sequences, BOXA1R (Louws 
et al., 1994). The reaction mixture consisted of $4 \mu \mathrm{l}$ DNA, $27.8 \mu 1 \mathrm{ddH}_{2} \mathrm{O}, 5 \mu 1$ 10x Taq buffer, $3 \mu 1 \mathrm{MgCl}_{2}, 8 \mu 10.1 \mathrm{mM}$ dNTPs, and $3.5 \mathrm{U}$ Taq Pol. The BOX-PCR conditions are given in Table 2. PCR products $(10 \mu \mathrm{l})$ were fractionated by gel electrophoresis ( $75 \mathrm{~V}$, for $7 \mathrm{~h}$ ) on $0.5 \%$ standard and $0.5 \%$ NuSieve agarose. A $1 \mathrm{~kb}$ DNA size marker (Fermantas, Vilnius, Lithuania) was used. The agarose gels were stained with ethidium bromide $(0.5 \mu \mathrm{g} / \mathrm{ml})$ for $20 \mathrm{~min}$., and pictured using a imaging system (Vilber Lourmat transilluminator, France). The outcomes were analysed by Bio-gene gel analysing software (VilberLourma, France). UPGMA (Sneath and Sokal, 1973) and Dice coefficient $(2 \mathrm{a} /(2 \mathrm{a}+\mathrm{b}+\mathrm{c})($ Dice, 1945) were utilized for the DNA fingerprint matching and dendrogram analyses.

Table 2. Bacterial isolates used for the study

\begin{tabular}{|c|c|c|c|c|c|c|c|c|c|}
\hline 竞高 & 莺 & 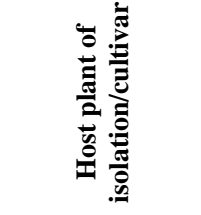 & 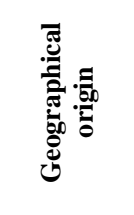 & 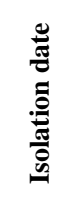 & 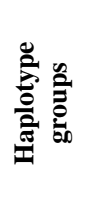 & 芳 & 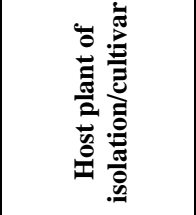 & 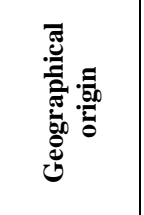 & 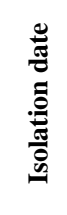 \\
\hline 1 & Pss 1 & Olive/Gemlik & Aksu & 2015 & 2 & Pss 13 & Olive/Gemlik & Antalya & 2015 \\
\hline 1 & Pss 2 & Olive/Gemlik & Aksu & 2015 & 2 & Pss 16 & Olive/Kan & Antalya & 2015 \\
\hline 1 & Pss 3 & Olive/Kan & Aksu & 2015 & 2 & Pss 20 & Olive/Edinciksu & Kaş & 2015 \\
\hline 1 & Pss 4 & Olive/Gemlik & Serik & 2015 & 2 & Pss 22 & Olive/Edremit & Kaş & 2015 \\
\hline 1 & Pss 6 & Olive/Gemlik & Dösemaltı & 2015 & 2 & Pss 24 & Olive/Memecik & Kaş & 2015 \\
\hline 1 & Pss 7 & Olive/Kan & Dösemalt1 & 2015 & 2 & Pss 25 & Olive/Kan & Antalya & 2015 \\
\hline 1 & Pss 9 & Olive/Kan & Dösemaltı & 2015 & 2 & Pss 26 & Olive/Gemlik & Antalya & 2015 \\
\hline 1 & Pss 10 & Olive/Edinciksu & Kaş & 2015 & 2 & Pss 29 & Olive/Ayvalık & Antalya & 2015 \\
\hline 1 & Pss 11 & Olive/Memeli & Kaş & 2015 & 2 & Pss 34 & Olive/Memecik & Antalya & 2015 \\
\hline 1 & Pss 14 & Olive/Gemlik & Dösemaltı & 2015 & 2 & Pss 38 & Olive/Edremit & Antalya & 2015 \\
\hline 1 & Pss 15 & Olive/Gemlik & Antalya & 2015 & 2 & Pss 41 & Olive/Kan & Kaş & 2016 \\
\hline 1 & Pss 17 & Olive/Kan & Antalya & 2015 & 2 & Pss 46 & Olive/Memecik & Kaş & 2016 \\
\hline 1 & Pss 18 & Olive/Edinciksu & Antalya & 2015 & 2 & Pss 50 & Olive/Gemlik & Kaş & 2016 \\
\hline 1 & Pss 27 & Olive/Gemlik & Antalya & 2015 & 2 & Pss 54 & Olive/Memeli & Antalya & 2016 \\
\hline 1 & Pss 28 & Olive/Gemlik & Kaş & 2015 & 2 & Pss 58 & Olive/Edinciksu & Kaş & 2016 \\
\hline 1 & Pss 31 & Olive/Gemlik & Dösemaltı & 2015 & 2 & Pss 59 & Olive/Edinciksu & Kaş & 2016 \\
\hline 1 & Pss 32 & Olive/Edinciksu & Serik & 2015 & 2 & Pss 62 & Olive/Ayvalık & Antalya & 2016 \\
\hline 1 & Pss 33 & Olive/Memecik & Serik & 2016 & 2 & Pss 65 & Olive/Gemlik & Antalya & 2018 \\
\hline 1 & Pss 35 & Olive/Gemlik & Serik & 2016 & 2 & Pss 67 & Olive/Gemlik & Antalya & 2018 \\
\hline 1 & Pss 36 & Olive/Gemlik & Kaş & 2016 & 3 & Pss 12 & Olive/Gemlik & Serik & 2015 \\
\hline 1 & Pss 37 & Olive/Memeli & Kaş & 2016 & 3 & Pss 19 & Olive/Edremit & Aksu & 2015 \\
\hline 1 & Pss 39 & Olive/Kan & Aksu & 2016 & 3 & Pss 21 & Olive/Memeli & Kaş & 2015 \\
\hline 1 & Pss 40 & Olive/Edinciksu & Dösemaltı & 2016 & 3 & Pss 23 & Olive/Kan & Aksu & 2015 \\
\hline 1 & Pss 42 & Olive/Kan & Dösemaltı & 2016 & 3 & Pss 30 & Olive/Gemlik & Serik & 2015 \\
\hline 1 & Pss 44 & Olive/Edremit & Dösemaltı & 2016 & 3 & Pss 43 & Olive/Gemlik & Serik & 2015 \\
\hline 1 & Pss 45 & Olive/Edremit & Serik & 2016 & 3 & Pss 49 & Olive/Gemlik & Kaş & 2016 \\
\hline 1 & Pss 47 & Olive/Kan & Serik & 2016 & 3 & Pss 53 & Olive/Gemlik & Kaş & 2016 \\
\hline 1 & Pss 48 & Olive/Gemlik & Kaş & 2016 & 3 & Pss 60 & Olive/Kan & Serik & 2016 \\
\hline 1 & Pss 51 & Olive/Gemlik & Kaş & 2016 & 3 & Pss 61 & Olive/Ayvalık & Dösemaltı & 2016 \\
\hline 1 & Pss 52 & Olive/Gemlik & Antalya & 2016 & 3 & Pss 66 & Olive/Gemlik & Dösemaltı & 2018 \\
\hline 1 & Pss 55 & Olive/Gemlik & Aksu & 2016 & 1 & PssI2 & Olive/Kan & Aksu & 2000 \\
\hline 1 & Pss 56 & Olive/Edinciksu & Aksu & 2016 & 1 & PssI7 & Olive/Kan & Serik & 2000 \\
\hline 1 & Pss 57 & Olive/Memecik & Kaş & 2016 & 1 & PssI21 & Olive/Kan & Kaş & 2000 \\
\hline 1 & Pss 63 & Olive/Memecik & Dösemaltı & 2018 & 4 & Pss I24 & Myrtus & Döşemaltı & 2000 \\
\hline 1 & Pss 64 & Olive/Kan & Dösemaltı & 2018 & 3 & Psn 9 & Nerium & Serik & 2000 \\
\hline 2 & Pss 5 & Olive/Kan & Aksu & 2015 & 1 & NCPPB639 & Olive & Yugoslavia & 1908 \\
\hline 2 & Pss 8 & Olive/Gemlik & Antalya & 2015 & & & & & \\
\hline
\end{tabular}




\section{PFGE}

The Psv isolates were cultured in $5 \mathrm{ml}$ Nutrient Broth at $28{ }^{\circ} \mathrm{C}$ at $140 \mathrm{rpm}$ shaking for $24 \mathrm{~h}$. Cell suspensions were adjusted to an OD of $0.3 \mathrm{~A}$ (approximately $1 \times 10^{8} \mathrm{CFU} / \mathrm{ml}$ ) at $600 \mathrm{~nm}$ by utilizing a spectrophotometer (Eppendorf, Hamburg, Germany). The bacterial suspensions $(1.5 \mathrm{ml})$ were centrifugated at $14,000 \mathrm{rpm}$ for $2 \mathrm{~min}$, pelleted, and resuspended in $1 \mathrm{ml}$ sterile $\mathrm{dH}_{2} \mathrm{O}$. This procedure was repeated twice. After suspension of the cells in $500 \mu \mathrm{TE}$ buffer $(10 \mathrm{mM}$ Tris-HCl, pH 8.0; $10 \mathrm{mM} \mathrm{MgCl} 2 ; 25 \mathrm{mM}$ EDTA, $\mathrm{pH} 8.0), 1 \times 10^{8} \mathrm{CFU} / \mathrm{ml}$ cells were encapsulated in 500 $\mu 12 \%(\mathrm{w} / \mathrm{v})$ low melting point agarose (Bio-Rad Laboratories, Hercules, CA, USA), and transferred into sterile fitting-molds (Bio-Rad Laboratories, Hercules, CA, USA). The hardened agarose fittings at $4{ }^{\circ} \mathrm{C}$ for 20 min were returned to a $1.5 \mathrm{ml}$ microfuge tube. Agarose fittings with $1 \mathrm{mg} / \mathrm{ml}$ Proteinase $\mathrm{K}$ in $250 \mathrm{mM}$ EDTA (pH 9.5) and 25\% $(\mathrm{w} / \mathrm{v}) \mathrm{N}$-laurylsarcosine were incubated overnight at $50{ }^{\circ} \mathrm{C}$. The agarose plugs were returned to a sterile tube containing $1.5 \mathrm{ml}$ sterile $250 \mathrm{mM}$ EDTA $(\mathrm{pH} 8.0)$ at $4{ }^{\circ} \mathrm{C}$ until used. Complete restriction digestion of $1 / 5$ of agarose fittings was performed with $15 \mathrm{U}$ of Spe I, Ase I, and Xba I (Hacioğlu et al., 1997) at $37^{\circ} \mathrm{C}$ for $7 \mathrm{~h}$. The fittings were inserted into $0.9 \%$ (w/v) agarose gel in $0.5 \mathrm{x}$ TBE buffer [44.5 mM Tris- $\mathrm{HCl}, 44.5 \mathrm{mM}$ Boric Acid, $1 \mathrm{mM}$ EDTA (pH 8.0)] at $14{ }^{\circ} \mathrm{C}$ all through the kept running by utilizing a pulsed field gel electrophoresis unit (CHEF-DR III) (Bio-Rad Laboratories Hercules, CA, USA).

The optimal migration condition was used, depending on DNA size, at $200 \mathrm{~V}$ with an angle of $120^{\circ}$, with an underlying switch time of $5 \mathrm{~s}$ and a last switch time of $45 \mathrm{~s}$ for $22 \mathrm{~h}$. The gel was stained with $0.5 \mathrm{x}$ TBE buffer containing $0.5 \mu \mathrm{g} / \mathrm{ml}$ ethidium bromide for 200 min. Low-Range (New England Biolabs, MA, USA) and Yeast Chromosomal PFGE (Saccharomyces cerevisiae) markers were utilized as molecular size markers. The gel image was obtained by using a VilberLourma Monochrome 1/2" IT CCD camera. DNA fingerprint patterns and sizes were analysed by Bio-gene gel imaging programming (Vilber Lourma, France). UPGMA (Sneath and Sokal, 1973) and Dice coefficient $(2 \mathrm{a} /(2 \mathrm{a}+\mathrm{b}+\mathrm{c})$ (Dice, 1945) were utilized for the DNA fingerprint matching and dendrogram analyses.

\section{Results}

\section{Isolation and identification of bacteria}

The isolates and their locations are given in Figure 1 and Table 2. The pathogens were characterized after isolation from infected olive trees, thereby establishing their presence across the various districts of Antalya province in Turkey. The incidence of the olive knot disease reported for each district by Bansal et al. (1994) are: $80 \%$ in Serik, 20\% in Döşemealt1-Kırkgöz, 17\% in Aksu-Topall1, 10\% in Kaş-Dalyan, and 4\% in Antalya-Center.

Psv grew well and produced unique levan-negative colonies on selective PVF-1, KB, and NSA media. The colonies grown on KB medium were flat, with a diameter ranging from 1-3 mm, greyish to white colour, and irregular margins. The bacteria produced fluorescence pigment on both KB and PVF-1 media under UV light. The colonies grown on PVF-1 were greyish white, slightly raised, smooth, and relatively small (2$3 \mathrm{~mm}$ ). The colonies grown on NSA medium were grey or pale yellow, slightly raised or flat with a diameter of 3-5 mm. LOPAT indicated negative levan, oxidase, potato 
soft rot, and arginine dehydrolase tests, but all isolates showed positive hypersensitive reaction in the tobacco plant. In all, 67 isolates were recovered from diseased olive trees in Turkey and identified by PCR. The numbers of groups and strains in each group are presented in Table 2.

The pathogenicity of the isolates on the one-year-old Gemlik olive seedlings produced characteristic knot symptoms with variable sizes. The healthy olive seedling treated with sterile $\mathrm{dH}_{2} \mathrm{O}$ as a control did not show any symptoms (Fig. 2a). The pathogen was reliably re-isolated from the knots in the repeated tests, establishing Psv as the causal agent of the knot or gall disease in olive plants, thereby satisfying Koch's postulates (Fig. $2 b$ and $c$ ).

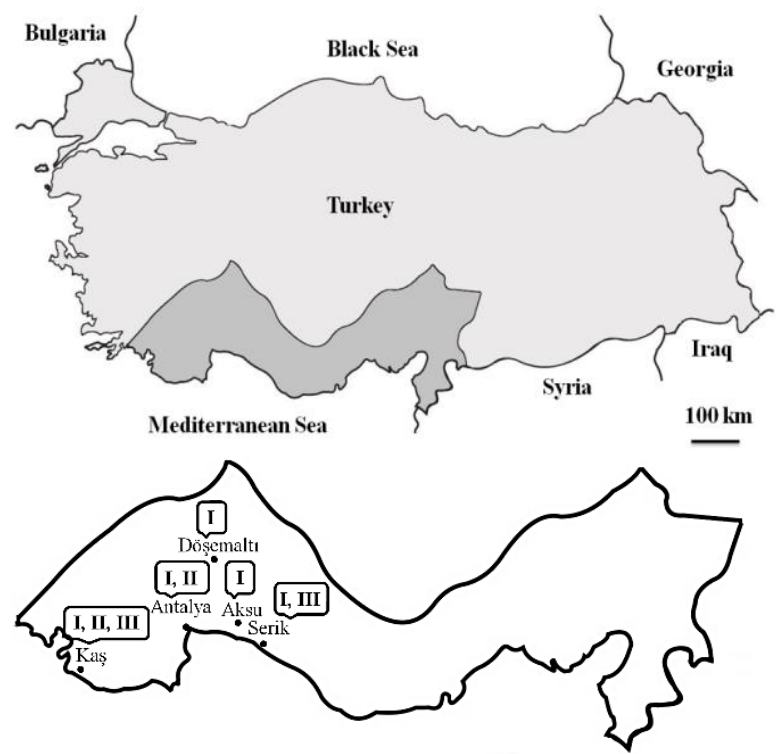

$100 \mathrm{~km}$

Figure 1. Distribution of Psv in the western Mediterranean region of Turkey as determined by PFGE analysis. Schematic map of the region showing the 5 districts studied. Letters next to the district names indicate the haplotype groups (I-III)
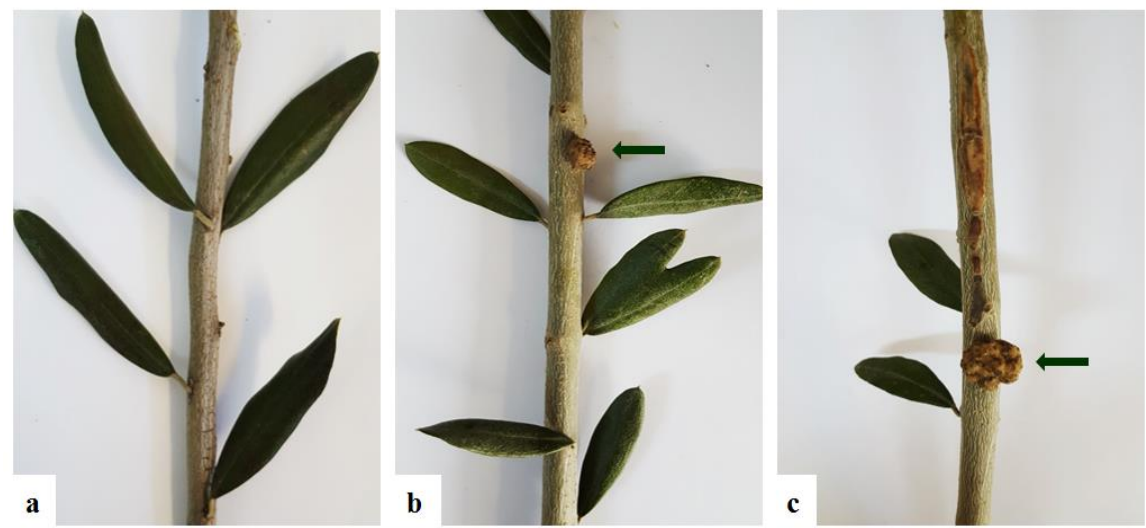

Figure 2. The pathogenicity of the isolates on a one-year-old Gemlik cultivar of olive seedlings; (a) healthy olive seedling treated with sterile $\mathrm{dH}_{2} \mathrm{O}$ used as a control, (b) seedling inoculated with the reference strain (NCPPB 639) showing knot symptoms, $(c)$ seedling inoculated with the Turkish isolate (Pss 2) showing knot symptoms 
The relationships among the $P s v$ strains were established based on FAME analysis. All 67 isolates recovered from the olive plant hosts in Antalya province and the reference strains were analysed. The results show percent similarities of $78.50-100 \%$ to the MIS library. The major fatty acids were palmitic acid (16:0), palmitoleic acid (16:1), and oleic acid (18:1) (Table 3). The FAME cluster analysis based on the Euclidean distance categorized the Turkish olive strains into 2 groups (Fig. 3). Each clade is unique, showing a close relationship among each other.

Table 3. The percentage values* of total fatty acid methyl esters (FAME) of Psv and Psn isolates

\begin{tabular}{c|c|c|c|c}
\hline \multirow{2}{*}{ FAME } & \multicolumn{4}{|c}{ Strain groups } \\
\cline { 2 - 5 } & I & II & III & Psn 9 \\
\hline $10: 0$ & $0.0 \pm 0.07$ & $0.0 \pm 0.02$ & $0.17 \pm 0.03$ & $0.0 \pm 0.01$ \\
$10: 03 \mathrm{OH}$ & $4.50 \pm 1.20$ & $4.38 \pm 1.04$ & $2.66 \pm 0.24$ & $4.28 \pm 0.11$ \\
$12: 00$ & $2.00 \pm 0.31$ & $6.07 \pm 0.52$ & $4.69 \pm 0.32$ & $2.59 \pm 0.04$ \\
$11: 00$ iso $3 \mathrm{HO}$ & $0.0 \pm 0.05$ & $0.0 \pm 0.06$ & $0.35 \pm 0.05$ & $0.0 \pm 0.01$ \\
$12: 02 \mathrm{OH}$ & $6.41 \pm 0.32$ & $4.40 \pm 0.01$ & $3.40 \pm 0.92$ & $5.88 \pm 0.68$ \\
$12: 03 \mathrm{OH}$ & $4.70 \pm 1.21$ & $5.27 \pm 1.12$ & $4.19 \pm 0.59$ & $4.21 \pm 0.67$ \\
$14: 0$ & $0.42 \pm 0.03$ & $0.0 \pm 0.01$ & $0.18 \pm 0.05$ & $0.43 \pm 0.07$ \\
$16: 1^{\mathrm{a}}$ & $34.60 \pm 2.58$ & $33.45 \pm 2.31$ & $22.98 \pm 2.73$ & $35.14 \pm 2.99$ \\
$16: 0^{\mathrm{b}}$ & $27.01 \pm 1.47$ & $20.72 \pm 1.78$ & $23.19 \pm 1.62$ & $26.53 \pm 1.25$ \\
$17: 0$ iso & $0.0 \pm 0.04$ & $0.0 \pm 0.02$ & $1.61 \pm 0.03$ & $0.0 \pm 0.01$ \\
$17: 0$ cyclo & $3.15 \pm 0.34$ & $0.0 \pm 0.05$ & $4.42 \pm 0.37$ & $2.87 \pm 0.46$ \\
$18: 1^{\mathrm{c}}$ & $15.34 \pm 3.05$ & $23.02 \pm 2.04$ & $27.40 \pm 2.81$ & $16.49 \pm 3.01$ \\
$18: 0$ & $1.09 \pm 0.54$ & $1.53 \pm 0.03$ & $2.80 \pm 0.89$ & $1.57 \pm 0.74$ \\
$18: 1$ w7c 11 -methyl & $0.0 \pm 0.03$ & $0.0 \pm 0.01$ & $1.13 \pm 0.02$ & $0.0 \pm 0.05$ \\
Sum In Feature 7 & $0.0 \pm 0.40$ & $1.15 \pm 0.20$ & $0.37 \pm 0.11$ & $0.0 \pm 0.02$ \\
$19: 0$ cyclo w8c & $0.0 \pm 0.04$ & $0.0 \pm 0.01$ & $0.46 \pm 0.02$ & $0.0 \pm 0.01$ \\
\hline
\end{tabular}

*Each value is an average \pm standard deviation of strain groups

I, II: Olive strain groups of Psv., III: Myrtus communis strain group of Psv

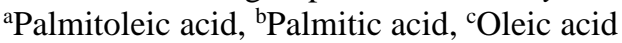

\section{Rep-PCR}

The primer, BOXA1R, which was used to amplify the repetitive DNA sequence of $P s v$, showed various genomic fingerprints. The results obtained by the BOXA1R primer pair showed variability among the $P s v$ strains. This primer pair produced different polymorphic patterns among the strains with amplification fragments ranging from $\sim 250$ to 2250 bp (Fig. 4). BOX PCR cluster analysis categorized all the Turkish olive strains into 2 groups (Fig. 5).

\section{PFGE}

All 67 isolates and reference strains were evaluated by using PFGE. The results showed various discrete DNA patterns of $P s v$ after digesting the total genome with SpeI. The restriction digestion of the Psv genome yielded fragments which ranged from 9 to $1000 \mathrm{~kb}$ (Fig. 6). Ase I and Xba I did not effectively digest genomic DNA in this study. The Turkish olive strains were separated into 3 discrete PFGE groups (Fig. 7). Based on the cluster analysis, there was nearly identical linkage between the haplotype 
group I and the reference strain. The percentage similarity among the haplotypes as shown by the cluster was $42-100 \%$ (Fig. 7). Based on the cluster analysis of PFGE, haplotype group I consisted of 38 haplotypes and reference strain NCPPB639; haplotype group II (21 haplotypes): haplotype group III (11 haplotypes), and the myrtus isolate was placed into haplotype group IV as Figure 7 and Table 2.

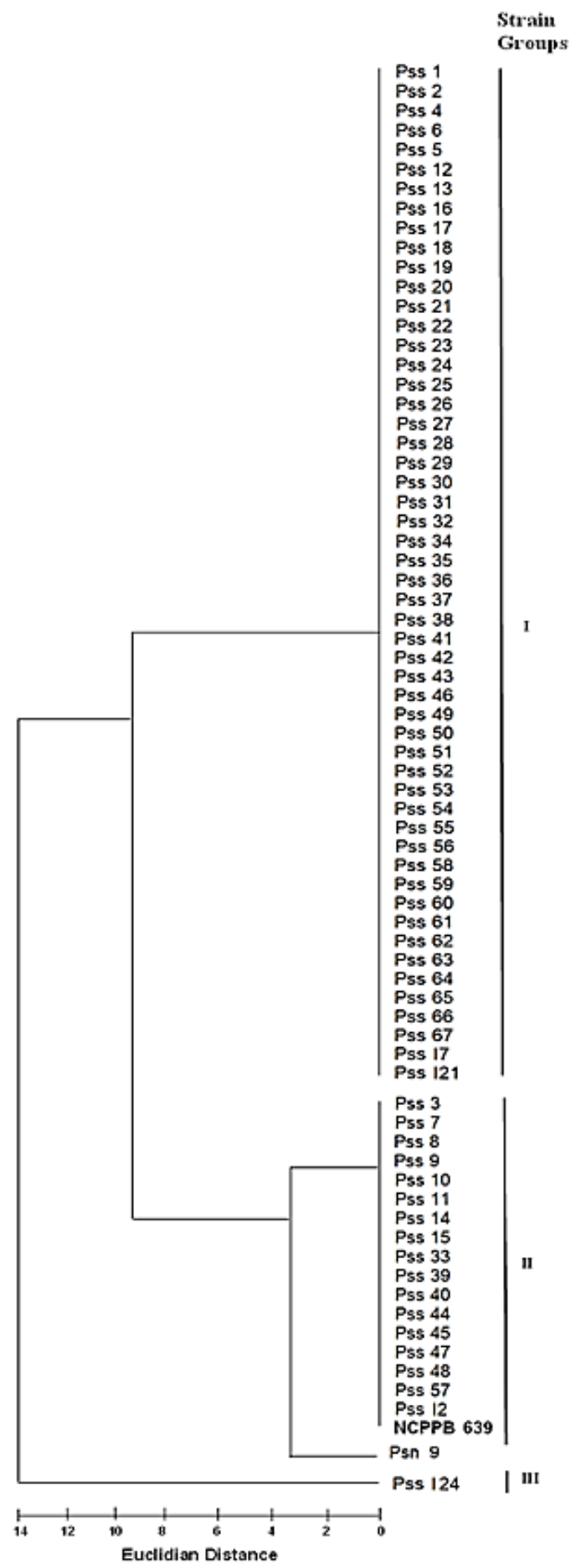

Figure 3. Dendrogram generated by cluster analysis of Psv strains (Table 2) based on fatty acid composition 

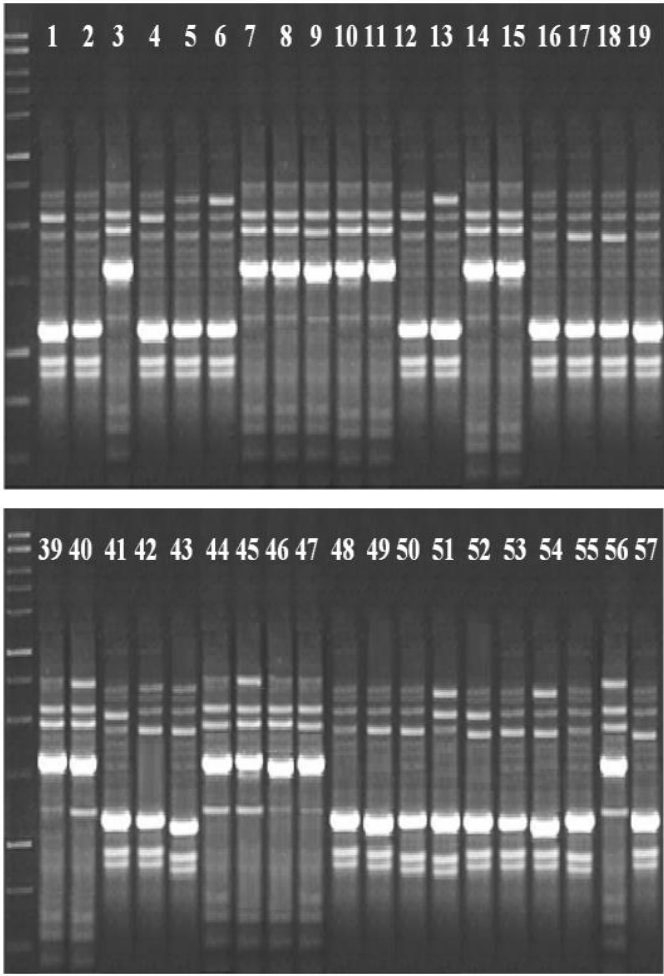
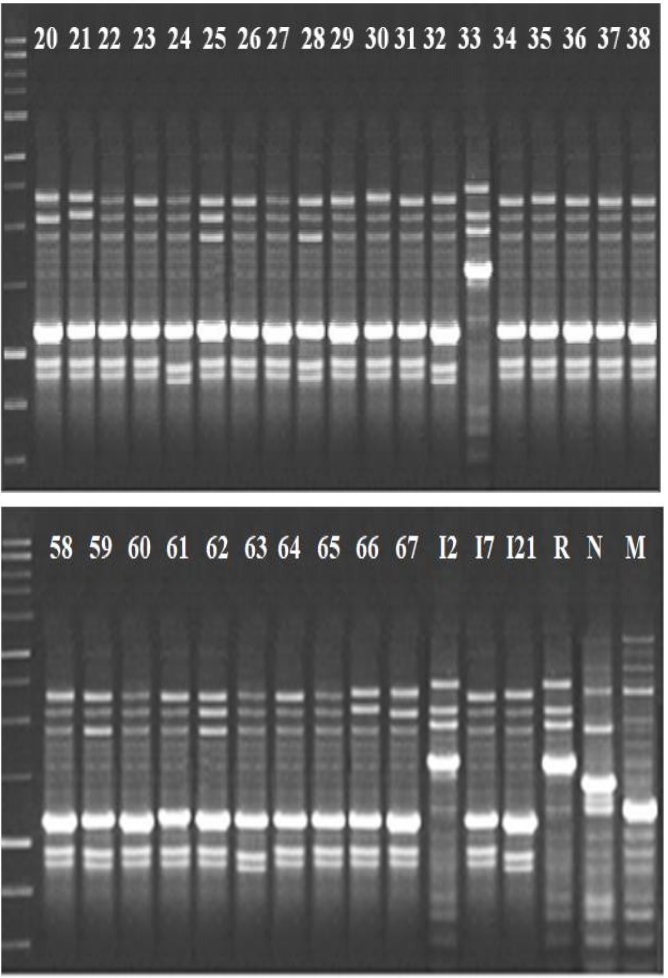

Figure 4. Agarose gel electrophoresis of repetitive sequence-based BOX-PCR fingerprint patterns obtained from Psv and Psn strains. Lanes: 1-67; Pss 1-Pss 67, respectively; Lane: I2, I7, I21, R, N, M; Pss I2, Pss I7, Pss I21, NCPPB 639, Psn 9, Pss I24, respectively

\section{Discussion}

Of the isolates collected from diseased olive plants during the 2015-2018 survey, 67 were found to be heterogenic and divided into 3 haplotype groups by PFGE. From the survey results, the highest percentage of the disease and the olive plant cultivars from which the pathogen were isolated were from the Serik district, and the highest infected $(80 \%)$ or susceptible cultivar from this district was the Gemlik cultivar. The least infected orchard recorded was from the Antalya-center district. When all the collected samples across the various districts were compared, the Gemlik cultivar showed the highest percentage of infection. Some commercial olive cultivars have been found to be considerably tolerant to olive knot disease (Penyalver et al., 2006). The high rate of infection in the Gemlik cultivar could be due to a high susceptibility to this pathogen. It could also be also be attributed to the exposure of these varieties to powerful winds common in the coastal regions of Antalya-center and Kaş-Dalyan. These strong winds create wounds on the plants which allow entrance for the pathogen. Additionally, the fungus, Cycloconium oleaginum, a causal agent of olive leaf spot disease that results in defoliation, creates wounds that can serve as entrance point for Psv.

The different groups of $P s v$ strains according to PFGE occurred in the same districts because of the large olive plant production as well as different cultivars of olive grown in these areas. There was no association of genetic diversity of Turkish Psv population with olive cultivars of isolation. The results of Scortichini et al. (2004) were supported by our findings. On the other hand, Moretti et al. (2008) and Krid et al. (2009) reported an association with geography and olive cultivars. 


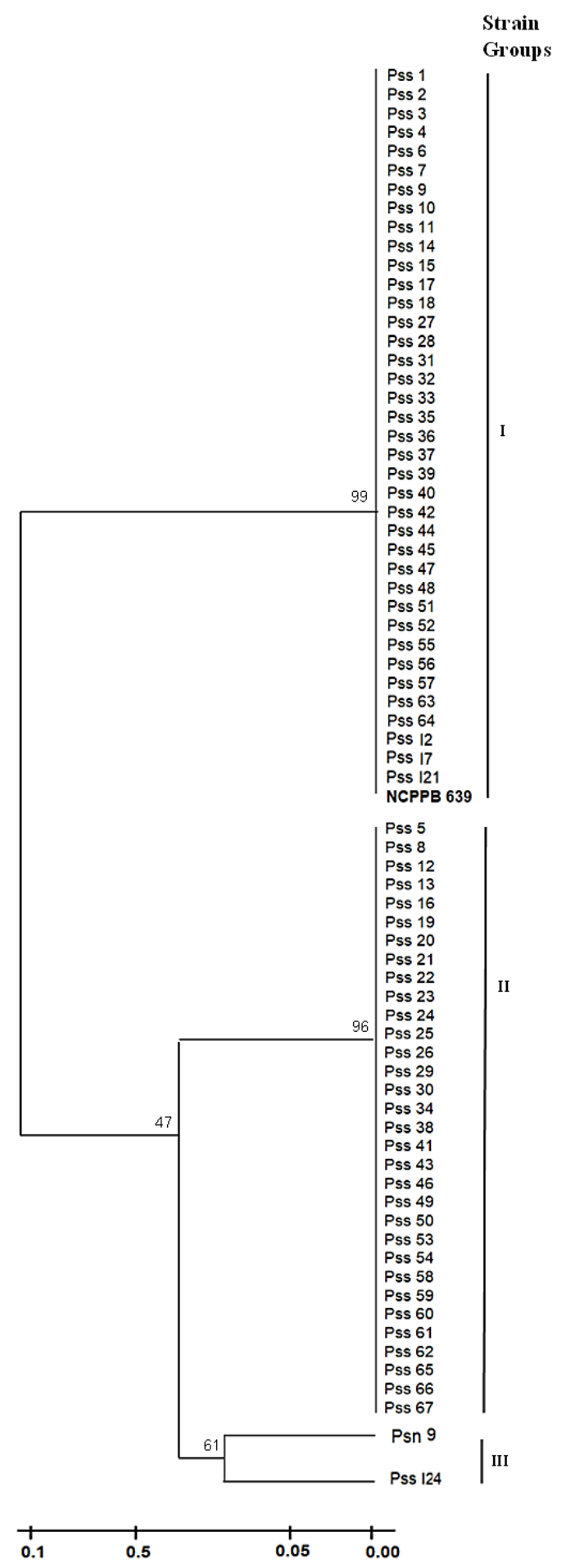

Figure 5. Unweighted average linkage dendrogram of the cluster analysis of Psv strains (Table 2) based on BOX-PCR analysis

Understanding the Psv population may help to enhance the present control management of olive knot disease. Psv isolates obtained from infected olive trees in various geographical region of the world are different. In a few studies, various Psv populations were gathered from various parts of the world, including 360 isolates from 
Italy (Scortichini et al., 2004), 71 isolates from Italy, USA, Greece, Portugal, former Yugoslavia, UK, the Netherlands, and France (Sisto et al., 2007), 62 isolates from Spain, Italy, Serbia, France, Portugal, USA, Algeria, Greece, Jordan, and Tunusia (Quesada et al., 2008), 58 strains from Tunusia (Krid et al., 2009), 31 isolates from Italy (Cinelli et al., 2014), 124 isolates from various Mediterranean countries (Moretti et al., 2017), and 19 isolates from Japan (Tsuji et al., 2017)

Scortichini et al. (2004) analysed 360 Italian Psv isolates and reported the presence of 20 DNA fingerprint patterns by rep-PCR. The 44 Spanish Psv isolates were grouped into 3 different groups, and the only 6 Italian isolates were placed into 3 different groups by the presence of IS53 (Quesada et al., 2008). The 58 Tunisian Psv isolates were clustered into 3 different groups by RAPD (Krid et al., 2009). Recently, Moretti et al. (2017) analysed $124 P s v$ isolates from 15 different countries and grouped the isolates into 2 clusters and 4 subclusters by MLST and rep-PCR. The 19 Japanese isolates were differentiated into 5 different groups by rep-PCR (Tsuji et al., 2017).
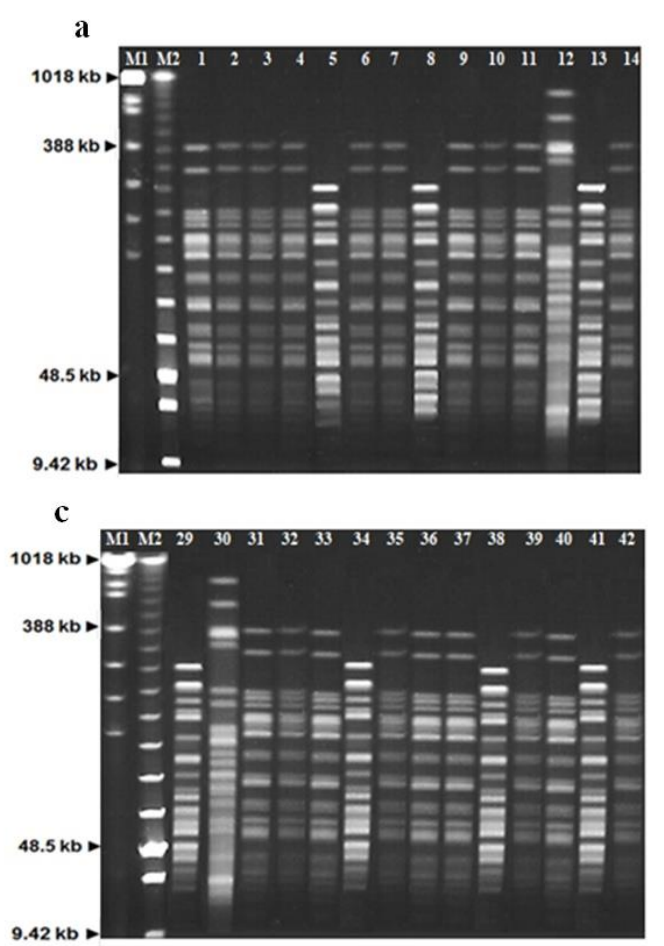
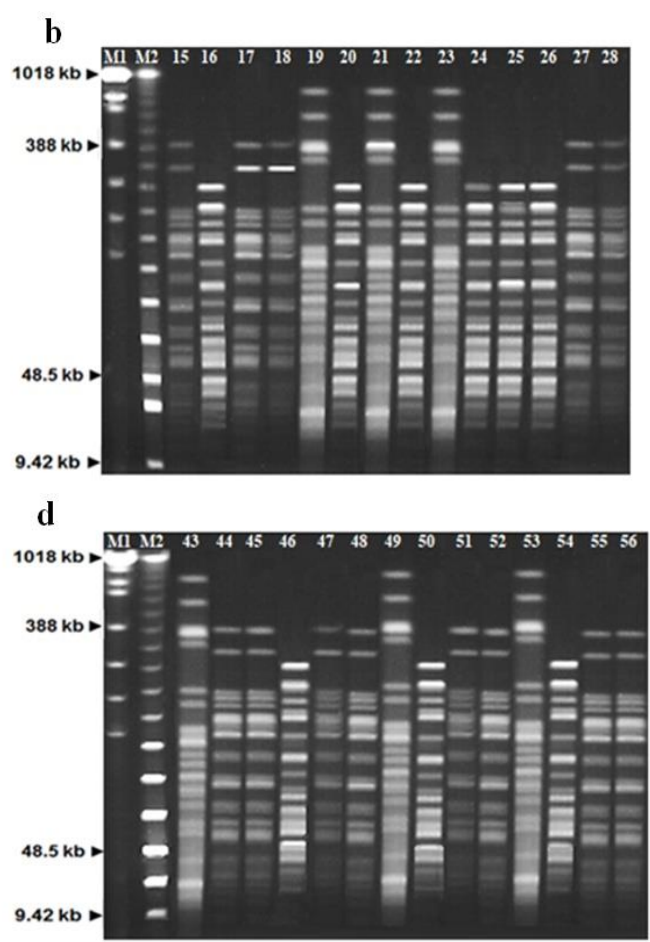

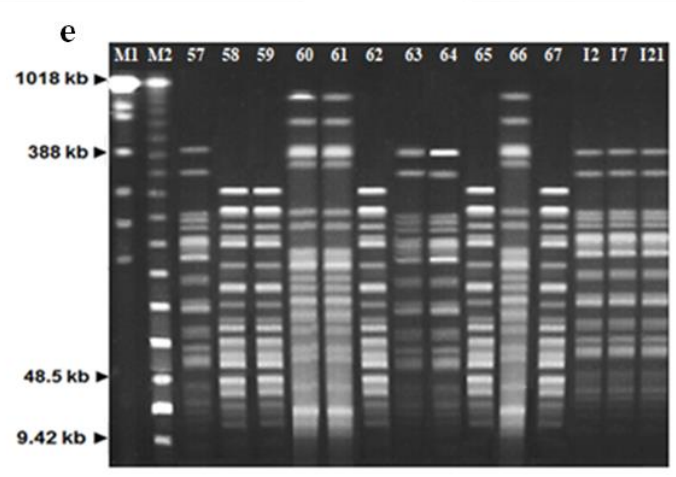

Figure 6. $(a, b, c, d, e)$ Genomic DNA fingerprints from olive strains of Psv in Turkey by PFGE using Spe I. Lanes: $M 1=D N A$ size standards of Saccharomyces cerevisiae, $M 2=$ Low-range PFGE marker. Lanes: $1-67=$ Pss 1-Pss67, respectively; Lane: $12, I 7, I 21=P s s I 2$, PssI7, PssI21, respectively 


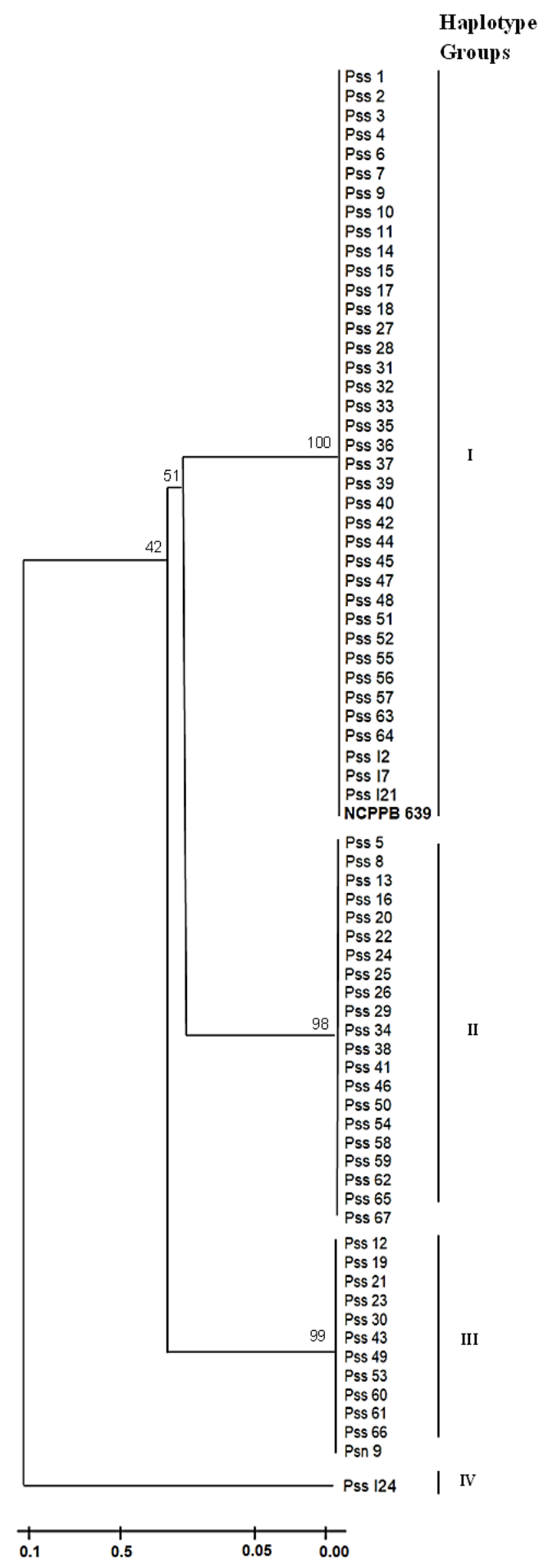

Figure 7. Unweighted average linkage dendrogram of cluster analysis of Psv (Table 2) haplotype groups generated by PFGE patterns with Spe I. Number of horizontal axes indicates percent similarity as determined by Dice coefficient

There have been reports of the presence of olive knot disease caused by Psv in the Aegean region, which is one of the olive growing provinces of Turkey (Tatli and Benlioğlu, 2004) and in the western Mediterranean region, specifically in Antalya 
province (Basim and Ersoy, 2000), in oleander plants in the South-eastern Anatolia, specifically in Şanlıurfa (Kavak and Üstün, 2009), and from the Adana, Samsun, and Tekirdağ provinces of Turkey (Mirik et al., 2011).

The morphological and biochemical tests indicated that the 3 media used in this study produced colonies typical of $P s v$. Considerable heterogeneity in the colonies established by Psv strains isolated from different cultivars of olive in various localities have been reported in Italy (Surico and Marchi 2003). LOPAT showed isolates to be levan negative, and all isolates produced a positive hypersensitive reaction in tobacco plant. The LOPAT profile (Lelliott et al., 1966) and other tests described by Lelliott and Stead (1987) were used to separate a typical Psv strain from $P$. syringae subsp. syringae. Janse (1981) observed that some $P s v$ strains isolated from various host plants had almost similar physiological and biochemical dispositions. All isolates were confirmed to be pathogenic on a one-year-old olive plant, but not on an oleander plant. Our result is in concordance with the findings reported by Perez-Martinez et al. (2007).

Table 3 indicates the relative (percent) total fatty acid methyl esters as found by FAME analysis of the Psv isolates, which were entered into the standard MIDI library. The FAME cluster categorized all the strains isolated from olive plants collected from various districts of Antalya province which were clustered into 2 groups based on Euclidean metrics. The FAME analysis provides useful information with regards to the phenotypic identification of the pathogen, but it is not an effective technique for discriminating between strains.

The diversity study was carried out using rep-PCR with primer pair, BOXA1R, which was found to be informative and discriminatory for all the $P s v$ isolates tested in this study, and produced polymorphic patterns corresponding to different amplification fragment sizes (Fig. 4). All the strains isolated from olive plants formed 2 groups based on the BOX-PCR. Although the BOX-PCR was found to be effective at differentiating Psv isolates, its discriminating ability was less than that of PFGE as observed in this study. Interestingly, it could be seen from the cluster tree that strains from different districts of a province or geographical location showed similar genetic homogeneity and were grouped together in one clade by the BOX-PCR cluster analysis (Fig. 5).

The genetic variability among the $P s v$ strains was further confirmed by using PFGE after restriction digestion with Spe I, a rare-cutting enzyme. Three different haplotype groups were produced based on the DNA fragment patterns generated as compared to FAME and BOX-PCR analyses, which categorized the isolates from olive plant hosts into 2 groups each. The results of this study recommend that the FAME and BOX-PCR strategies were not capable as PFGE to separate $P s v$ strains. The PFGE utilizing rarecutting endonuclease Spe I given the foremost comprehensive comes about. The effective discriminatory ability and reproducibility of PFGE makes it one of the foremost broadly utilizied method for comparative fingerprinting of most bacterial species (Sails et al., 2003; Lukinmaa et al., 2004; van Belkum et al., 2007). Based on PFGE, most Psv strains were placed in haplotype group I with reference strain NCPPB639. The other strains were separated into 2 haplotype groups, resulting in a total 3 different haplotype groups in the olive $P s v$ population. This heterogeneity among the Psv population can be clarified by even exchange of plasmids and chromosomal genes as seen in Xanthomonas and Pseudomonas pathovars (Canteros et al., 1995; Basim et al., 1999; Sundin, 2007). Based on PFGE, the isolate Pss 9 from Nerium oleander was placed in haplotype group II, along with several olive strains. However, the same strain was placed in a different haplotype group by rep-PCR analysis. 
Comparative comes about were found by Moretti et al. (2017). P. s. pv. nerii and P. s. pv. fraxinii were plainly isolated from the $P s v$ population by utilizing rep-PCR. Based on MLST, isolates of $P$. s. pv. nerii and $P$. s. pv. fraxini pathovars clearly have a same genetic feature as $P s v$, and may have adjusted to oleander and fraxinus, individually, after $P s v$ risen as an olive plant pathogen (Moretti et al., 2017).

\section{Conclusion}

Our results show that PFGE using SpeI has an effective discriminatory capability for genotypic analysis of $P s v$ population. The present study provides important outputs to better comprehension of the genotypic and phenotypic structure of the Psv population in Turkey. The results about given an incredible opportunity for following strain shifting in the Psv population in future, and for olive breeding programs pointed at the advancement of an olive cultivar safe to the distinctive $P s v$ strains.

Acknowledgement. Our sincere gratitude to Scientific Research Projects (BAP) of Akdeniz University for their financial support.

\section{REFERENCES}

[1] Bansal, V. K., Kharbanda, P. D., Stringam, G. R., Thiagarajah, M. R., Tewari, J. P. (1994): A comparison of greenhouse and field screening methods for blackleg resistance in doubled haploid lines of Brassica napus. - Plant Dis. 78: 276-281.

[2] Basim, H., Ersoy, A. (2000): Identification and spread on Pseudomonas savastanoi pv. savastanoi caused by knot disease on olive in western Mediterranean region. - Turkish First Olive Symp., Bursa, Turkey, pp. 310-315.

[3] Basım, H., Ersoy, A. (2001): Identification of Pseudomonas savastanoi pv. savastanoi, olive knot pathogen, by polymerase chain reaction. - Phytopathol. 91: 6.

[4] Basim, H., Stall, R. E., Minsavage, G. V., Jones, J. B. (1999): Chromosomal gene transfer by conjugation in the plant pathogen Xanthomonas axonopodis pv. vesicatoria. Phytopathol. 89: 1044-1049.

[5] Berge, O., Monteil, C. L., Bartoli, C., Chandeysson, C., Guilbaud, C., Sands, D. C., Morris, C. E. (2014): A user's guide to a data base of the diversity of Pseudomonas syringae and its application to classifying strains in this phylogenetic complex. - PLoS One 9(9): e105547.

[6] Canteros, B. I., Minsavage, G. V., Jones, J. B., Stall, R. E. (1995): Diversity of plasmids in Xanthomonas campestris pv. vesicatoria. - Phytopathol. 85: 1482-1486.

[7] Chu, G., Vollrath, D., Davis, R. W. (1986): Separation of large DNA molecules by contour-clamped homogeneous electric fields. - Science 234: 1582-1585.

[8] Cinelli, T., Marchi, G., Cimmino, A., Marongiu, R., Evidente, A., Fiori, M. (2014): Heterogeneity of Pseudomonas savastanoi populations infecting Myrtus communis in Sardinia (Italy). - Plant Pathol. 63: 277-289.

[9] Doyle, J. J., Doyle, J. L. (1990): Isolation of plant DNA from fresh tissue. - Focus 12: 13-15.

[10] Dice, L. R. (1945): Measures of the amount of ecologic association between species. Ecol. 26: 297-302.

[11] Gardan, L., Bollet, C., Abu, G. M., Grimont, F., Grimont, P. A. D. (1992): DNA relatedness among the pathovar strains of Pseudomonas syringae subsp. savastanoi Janse (1991) and proposal of Pseudomonas savastanoi sp. nov. - Int. J. Syst. Bacteriol. 42: 606-612. 
[12] Guilbaud, C., Morris, C. E., Barakat, M., Ortet, P., Berge, O. (2016): Isolation and identification of Pseudomonas syringae facilitated by a PCR targeting the whole $P$. syringae group. - FEMS Microbiol. Ecol. 92(1): fiv146.

[13] Hacıoğlu, E., Basım, H., Stall, R. E. (1997): Optimized conditions of Pac I and Swa I for genome analysis of Xanthomonas axonopodi spv. vesicatoria by PFGE. - Biotechn. 22: 1026-1028.

[14] Hosni, T., Moretti, C., Devescovi, G., Suarez-Moreno, Z. R., Fatmi, M. B., Guarnaccia, C., Pongor, S., Onofri, A., Buonaurio, R., Venturi, V. (2011): Sharing of quorum-sensing signals and role of interspecies communities in a bacterial plant disease. - ISME J. 5: 1857-1870.

[15] Hulton, C. S. J., Higgins, C. F., Sharp, P. M. (1991): ERIC sequences: a novel family of repetitive elements in the genomes of Escherichia coli, Salmonella typhimurium and other enterobacteria. - Mol. Microbiol. 5: 825-834.

[16] International Olive Oil Council (2015): http://www. internationaloliveoil.org. - Accessed: 15 April 2016.

[17] Janse, J. D. (1981): The bacterial disease of ash (Fraxinus excelsior) caused by Pseudomonas syringae subsp. savastanoi pv. fraxini, II etiology and taxonomic considerations. - Eur. J. Forest Pathol. 11: 425-438.

[18] Kavak, H., Üstün, N. (2009): Oleander knot caused by Pseudomonas savastanoi pv. nerii in Turkey. - J. Plant Pathol. 91: 701-703.

[19] King, E. O., Ward, M. K., Raney, D. E. (1954): Two simple media for the demonstration of pyocyanin and fluorescein. - The J. Lab. Clin. Medic. 44: 301-307.

[20] King, G. J. (1989): Plasmid analysis and variation in Pseudomonas syringae. - The J. Appl. Bacteriol. 67: 489-496.

[21] Krid, S., Rhouma, A., Quesada, J. M., Penyalver, R., Gargouri, A. (2009): Delineation of Pseudomonas savastanoi pv. savastanoi strains isolated in Tunisia by random-amplified polymorphic DNA analysis. - J. Appl. Microbiol. 106: 886-894.

[22] Lelliott, R. A., Stead, D. E. (1987): Diagnostic procedures for bacterial plant diseases. In: Preece, T. F. (ed.) Methods in Plant Pathology. Vol. 2. Blackwell Scientific Publications, Oxford, UK.

[23] Lelliott, R. A., Billing, E., Hayward, A. C. (1966): A determinative scheme for fluorescent plant pathogenic bacteria. - J. Appl. Bacteriol. 29: 470-489.

[24] Loumou, A., Giourga, C. (2003): Olive groves: "The life and identity of the Mediterranean". - Agric. and Hum. Values 20: 87-95.

[25] Louws, F. J., Fulbright, D. W., Stephens, C. T., De Bruijn, F. J. (1994): Specific genomic fingerprints of phytopathogenic Xanthomonas and Pseudomonas pathovars and strains generated with repetitive sequences and PCR. - Appl. Environ. Microbiol. 60: 22862295.

[26] Lukinmaa, S., Nakari, U. M., Eklund, M., Siitonen, A. (2004): Application of molecular genetic methods in diagnostics and epidemiology of food-borne bacterial pathogens. APMIS 112: 908-929.

[27] Manceau, C., Horvais, A. (1997): Assessment of genetic diversity among strains of Pseudomonas syringae by PCR-restriction fragment length polymorphism analysis of rRNA operons with special emphasis on P. syringae pv. tomato. - Appl. Environ. Microbiol. 63: 498-505.

[28] Mirik, M., Aysan, Y., Sahin, F. (2011): Characterization of Pseudomonas savastanoi pv. savastanoi strains isolated from several host plants in Turkey and report of fontanesia as a new host. - J. Plant Pathol. 93: 263-270.

[29] Moretti, C., Ferrante, P., Hosni, T., Valentini, F., D’Onghia, A., Fatmi, M. B., Buonaurio, R. (2008): Characterization of Pseudomonas Savastanoi pv. Savastanoi Strains Collected from Olive Trees in Different Countries. - In: Fatmi, M. et al. (eds) Pseudomonas Syringae Pathovars and Related Pathogens - Identification, Epidemiology and Genomics. Springer, New York, pp. 321-329. 
[30] Moretti, C., Vinatzer, B. A., Onofri, A., Valentini, F., Buonaurio, R. (2017): Genetic and phenotypic diversity of Mediterranean populations of olive knot pathogen, Pseudomonas savastanoi pv. Savastanoi. - Plant Pathol. 66: 595-605.

[31] Nester, E. W., Kosuge, T. (1981): Plasmids specifying plant hyperplasias. - Ann. Rev. Microbiol. 35: 531-565.

[32] Penyalver, R., Garcia, A., Ferrer, A., Bertolini, E., Lopez, M. M. (2000): Detection of Pseudomonas savastanoi pv. savastanoi in olive plants by enrichment and PCR. - Appl. Environ. Microbiol. 66: 2673-2677.

[33] Penyalver, R., Garcia, A., Ferrer, A., Bertolini, E., Quesada, J. M., Salcedo, C. I., Piquer, J., Pérez-Panadés, J., Carbonell, E. A., del Río, C., Caballero, J. M., López, M. M. (2006): Factors affecting Pseudomonas savastanoi pv. savastanoi plant inoculations and their use for evaluation of olive cultivar susceptibility. - Phytopathol. 96: 313-319.

[34] Perez-Martínez, I., Rodríguez-Moreno, L., Matas, I. M., Ramos, C. (2007): Strain selection and improvement of gene transfer for genetic manipulation of Pseudomonas savastanoi isolated from olive knots. - Res. Microbiol 158: 60-69.

[35] Perez-Martínez, I., Rodríguez-Moreno, L., Lambertsen, L., Matas, I. M., Murillo, J., Tegli, S., Jiménez, A. J., Ramos, C. (2010): Fate of a Pseudomonas savastanoi pv. savastanoi type III secretion system mutant in olive plants (Olea europaea L.). - Appl. Environ. Microbiol. 76: 3611-3619.

[36] Quesada, J. M., Perez-Martinez, I., Ramos, C., Lopez, M. M., Penyalver, R. (2008): IS53: an insertion element for molecular typing of Pseudomonas savastanoi pv. savastanoi. Res. Microbiol. 159: 207-215.

[37] Quesada, J. M., Penyalver, R., Perez-Panades, J., Salcedo, C. I., Carbonell, E. A., Lopez, M. M. (2010): Comparison of chemical treatments for reducing epiphytic Pseudomonas savastanoi pv. savastanoi populations and for improving subsequent control of olive knot disease. - Crop Protect. 29: 1413-1420.

[38] Rodriguez-Palenzuela, P., Matas, I. M., Murillo, J., Lopez-Solanilla, E., Bardaji, L., Perez-Martinez, I., Rodriguez-Moskera, M. E., Penyalver, R., Lopez, M. M., Quesada, J. M., Biehl, B. S., Perna, N. T., Glasner, J. D., Cabot, E. L., Neeno-Eckwall, E., Ramos, C. (2010): Annotation and overview of the Pseudomonas savastanoi pv. savastanoi NCPPB 3335 draft genome reveals the virulence gene complement of a tumour-inducing pathogen of woody hosts. - Environ. Microbiol. 12: 1604-1620.

[39] Sails, A. D., Swaminathan, B., Fields, P. I. (2003): Utility of multilocus sequence typing as an epidemiological tool for investigation of outbreaks of gastroenteritis caused by Campylobacter jejuni. - J. Clinic. Microbiol. 41: 4733-4739.

[40] Schaad, N. W., Jones, J. B., Chun, W. (2001): Initial Identification of Common Genera. In: Schaad, N. W. et al. (eds.) Laboratory Guide for Identification of Plant Pathogenic Bacteria. 3th Ed. APS Press, St. Paul. MN, pp. 84-120.

[41] Schroth, M. N., Osgood, J. W., Miller, T. D. (1973): Quantitative assessment of the effect of the olive knot disease on olive yield and quality. - Phytopathol. 63: 1064-1065.

[42] Scortichini, M., Rossi, M. P., Salerno, M. (2004): Relationship of genetic structure of Pseudomonas savastanoi pv. savastanoi populations from Italian olive trees and patterns of host genetic diversity. - Plant Pathol. 53: 491-497.

[43] Sharples, G. J., Lioyd, R. G. (1990): A novel repeated DNA sequence located in the intergenic regions of bacterial chromosomes. - Nucl. Acids Res. 18(22): 6503-6508.

[44] Sisto, A., Cipriani, M. G., Morea, M. (2004): Knot formation caused by Pseudomonas syringae subsp. savastanoi on olive plants is hrp-dependent. - Phytopathol. 94(5): 484489.

[45] Sisto, A., Cipriani, M. G., Tegli, S., Cerboneschi, M., Stea, G., Santilli, E. (2007): Genetic characterization by fluorescent AFLP of Pseudomonas savastanoi pv. savastanoi strains isolated from different host species. - Plant Pathol. 56: 366-372.

[46] Sneath, P. H. A., Sokal, R. R. (1973): Numerical Taxonomy: The Principles and Practice of Numerical Classification. - Freeman, San Francisco, CA. 
[47] Stead, D. E. (1992): Grouping of plant pathogenic and some other Pseudomonas species by using cellular fatty acid profiles. - Inter. J. System. Evol. Microbiol. 42: 281-295.

[48] Sundin, G. W. (2007): Genomic insights into the contribution of phytopathogenic bacterial plasmids to the evolutionary history of their hosts. - Annu. Rev. Phytopathol. 45: $129-151$.

[49] Surico, G., Lavermicocca, P. (1989): A semiselective medium for the isolation of Pseudomonas syringae pv. savastanoi. - Phytopathol. 79: 185-190.

[50] Surico, G., Marchi, G. (2003): Olive Knot Disease: New Insights into the Ecology, Physiology and Epidemiology of Pseudomonas Savastanoi pv. Savastanoi. - In: Iacobellis, N. S. (ed.) Pseudomonas Syringae and Related Pathogens. Kluwer Academic, Netherlands, pp. 17-28.

[51] Surico, G., Iacobellis, N. S., Sisto, S. (1985): Studies on the role of indole-3-acetic acid and cytokinins in the formation of knots on olive and oleander plants by Pseudomonas syringae pv. savastanoi. - Physiol. Plant Pathol. 26: 309-320.

[52] Tatlı, B., Benlioğlu, K. (2004): Study on olive knot disease (Pseudomonas savastanoi pv. savastanoi) occurring olive areas of Aydın and Muğla provinces. - Proceed. $1^{\text {st }}$ Plant Protect. Congr., Samsun, Turkey.

[53] Tegli, S., Gori, A., Cerboneschi, M., Cipriani, M. G., Sisto, A. (2011): Type three secretion system in Pseudomonas savastanoi pathovars: does timing matter? - Genes 2: 957-979.

[54] Tsuji, M., Ohta, K., Tanaka, K., Takikawa, Y. (2017): Comparison among Japanese isolates of Pseudomonas savastanoi pv. savastanoi, causal agent of olive knot disease. J. General Plant Pathol. 83: 152-161.

[55] van Belkum, A., Tassios, P. T., Dijkshoorn, L., Haeggman, S., Cookson, B., Fry, N. K., Fussing, V., Green, J., Feil, E., Gerner-Smidt, P., Brisse, S., Struelens, M. (2007): Guidelines for the validation and application of typing methods for use in bacterial epidemiology. - Clinical Microbiol. Infect. 3: 1-46.

[56] van Zyl, E., Steyn, P. L. (1990): Differentiation of phytopathogenic Pseudomonas and Xanthomonas species and pathovars by numerical taxonomy and protein gel electropherogram. - Syst. Appl. Microbiol. 13: 60-71. 